\title{
STRATEGY IMPLEMENTATION ASSESSMENT OF THE SMEs IN HANDICRAFT INDUSTRY
}

\author{
Rodhiah HUSIN $^{a *}$, Toto Mujio MUKMIN ${ }^{b}$, Nur HIDAYAH ${ }^{c}$ \\ a, b, c Tarumanagara University, Indonesia
}

DOI: $10.24818 / \mathrm{IMC} / 2020 / 03.16$

\begin{abstract}
The existence of creative industries in Indonesia is very diverse. Each province has creative industries that illustrate the character of each region. Banten Province, which consists of four counties and four cities with the creative industry, is diverse, such as fisheries, craft, design, music, publishing and printing, and more. One of the provinces of Banten is South Tangerang, which has various creative industries that form in several creative communities. This study aims to determine excellence, weakness, opportunities, threats and analyze SMEs' competitive advantage and creative industryfocused sector craft in South Tangerang. Data collection was by purposive sampling on 20 SMEs in the craft industry. Collecting data is done through observation, interviews, and focus group discussions with SMEs and the Department of Koperindag Tangerang Selatan. The research method used qualitatively assessing the strengths, advantages, opportunities, and threats (SWOT analysis). The study result showed 15 strategies that SMEs must do in developing the creative industries craft in South Tangerang.
\end{abstract}

KEYWORDS: craft sector creative industry, SMEs, SWOT, competitive advantage

\section{INTRODUCTION}

Creative and innovative developments are proliferating. A million innovative products have the potential to penetrate the global market. In developed countries have realized the many innovative products on the market. This condition could separate from the existence of creative human resources. It shows that awareness of the creative industry is getting higher. UK DCMS Task Force (1998) states: Creative Industries as "those industries which have their origin in individual creativity, skill, and talent, and which have a potential for weal and job creation through the generation and exploitation of intellectual property and content" (Florida, 2013). The creative development industry in Indonesia has not been fully paid attention to and touched by the government, and it showed in one of the creative industry data in Banten Province. From the data from the Koperindag, as well-known that Banten province has a vast creative industry. However, this potential has not been fully noticed and touched by the Provincial Government. The official statistical data released by BPS Banten province shows that in February 2017, the Banten Province open unemployment rate which reached $7.75 \%$ (higher than the national figure of 5.33\%), shows that the role of the creative economy sector has not been optimal in overcoming the problem of unemployment through the importance of the creative economy.

Larassaty (2016) states that the creative economy has a significant role in improving the economy, public welfare, opening new jobs, and reducing unemployment. This problem seems to be one reason for the not yet optimal development of Indonesia's creative industry sector, making it difficult to outperform competitors. Jurnarsih (2005) revealed that creativity and innovation affect competitive

\footnotetext{
* Corresponding author. E-mail address: rodhiah@fe.untar.ac.id
} 
advantage, which is an advantage based on creativity in principle theory. Innovation is indispensable for creative business owners to take advantage of changing business opportunities; therefore, entrepreneurs need to look for sources of innovation, change, and symptoms that indicate an opportunity to succeed. To achieve the creative industry developed in Banten province is not easy; many obstacles and challenges; not all of the creative industry's problems are the same. So, this research aims to formulate a strategy assessment on the creative industries craft in Tangerang Selatan by using SWOT. The SWOT analysis provides a framework for analyzing internal strengths and weaknesses and external opportunities and threats. It helps to minimize the weaknesses and take advantage of the best opportunities available. The results of considering these two factors are "significant because they clarify the world in which the business or unit operates, making it possible to get a better picture for the desired future" (Brad \& Brad, 2015; Cojanu \& Bilbor, 2007; Kew \& Stredwick, 2010; Pahl \& Richter, 2009; Sarbah \& Otu-Nyarko, 2014; Sevkli, 2012). For this reason, the researchers conducted perform analysis on internal and external that can be determined to determine the competitive position of craft industry SMEs today and the potential growth of SMEs.

\section{LITERATURE REVIEW}

Management process strategies were evaluated with the internal and external conditions in SME done and implementations. With the internal and external factors that affect their activities. The evaluated process by SWOT. Sevkli (2012) SWOT analysis evaluates the overall strengths, weaknesses, opportunities, and threats. "Through this analysis, SMEs can analyze patterns of strengths and weaknesses, and business units do not have to correct all their weaknesses or utilize all their strengths. Developing the strategy must first identify various factors that systematically maximize strengths and opportunities and minimize weaknesses and threats. This analysis is called SWOT analysis, with definitions shown in Tables 1. (Zimmerer et al., 2008).

Table 1. Identification of Strengths \& Weaknesses, Opportunities \& Threats

\begin{tabular}{|l}
\hline \multicolumn{1}{|c|}{ Strengths } \\
$\begin{array}{l}\text { Companies can use it to achieve: mission, That inhibits the achievement of a company's mission, } \\
\text { objectives, and goals by using positive } \\
\text { internal factors }\end{array}$ \\
\hline \multicolumn{1}{|c|}{ Oppoals, and objectives are negative internal factors } \\
\hline $\begin{array}{l}\text { Favorable external options that companies } \\
\text { can utilize to accomplish the mission, } \\
\text { goals, and objectives. }\end{array}$ \\
\hline
\end{tabular}

Source: (Zimmerer et al., 2008).

\section{RESEARCH METHODS}

This research was conducted on the creative industry in the craft sector in South Tangerang, Banten Province, which includes several areas: Pamulang, Ciputat, Serpong, Bintaro, and others. The sample was done by convenience sampling, with as many as 20 SMEs in the handicraft sector. The sources of research data are:

a. Primary Data Source Primary data is obtained from the first source, either from individuals by interviews or filling out questionnaires done by researchers (Husein, 2000). Primary data in this study obtained through in-depth interviews and direct observation on batik craft industry creativity. Samples of the products are: 


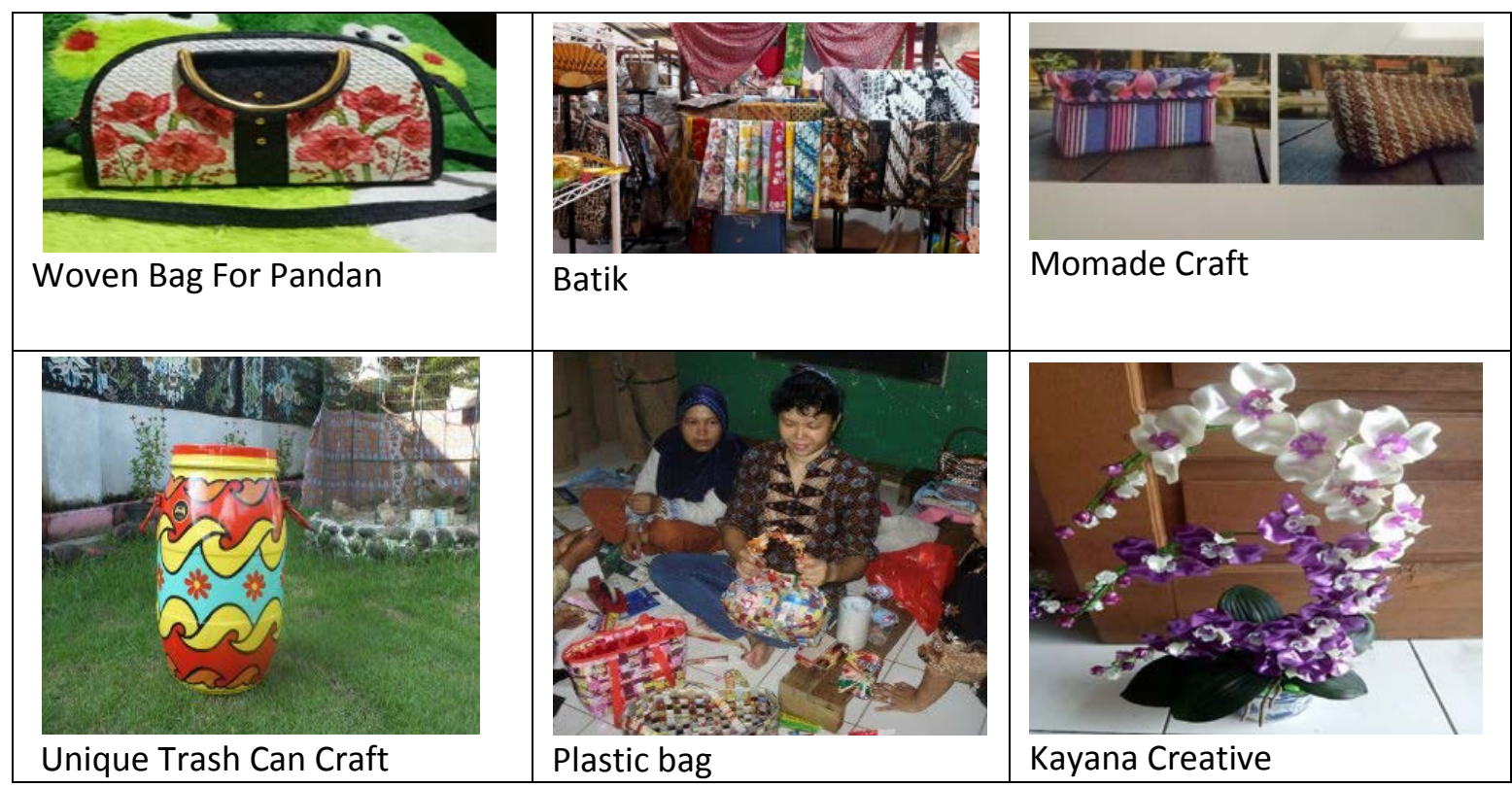

Figure 1. Overview of Industry Creative Product

b. Secondary Data Sources Secondary data is research data obtained by researchers indirectly or through a media intermediary (obtained and recorded by other parties). The data used in this study are data from the literature study, Tangerang Selatan Koperindag Office, and from the South Tangerang creative industry association or community.

To answer the problem is to analyze the method faced by Craft SMEs that have selected as research samples, the following analytical methods used: SWOT analysis is an analysis carried out by describing the implementation of marketing strategies through strengths, weaknesses, opportunities, and threats. The Strength- Weakness-Opportunity-Threat (SWOT) matrix is vital tool help managers develop four types of strategies, namely SO (strength-opportunities), WO (weakness-opportunities), ST (strengths-threats), WT (weaknesses-threats)), ST (strengths threats), dan WT (weaknessesthreats).

\section{RESEARCH RESULT}

Assessment Model Strategy. The model for assessing the strengths, weaknesses, opportunities, and threats is using a SWOT analysis as a basis for assessing the extent to which the success of SMEs in South Tangerang. It is related to what efforts SMEs should make in developing future businesses. The SWOT result showed in Table 2.

Table 2 Tang-Sel Craft Product SWOT

\begin{tabular}{|c|c|c|c|}
\hline $\begin{array}{l}\text { S - Strength } \\
\text { (Strength) }\end{array}$ & $\begin{array}{l}\text { W - Weakness } \\
\text { (Weakness) }\end{array}$ & $\begin{array}{c}\text { O - Opportunities } \\
\text { (Opportunities) }\end{array}$ & T - Threats (Threats) \\
\hline $\begin{array}{l}\text { - Having expertise } \\
\text { as a craftsman } \\
\text { - Availability of } \\
\text { raw materials }\end{array}$ & 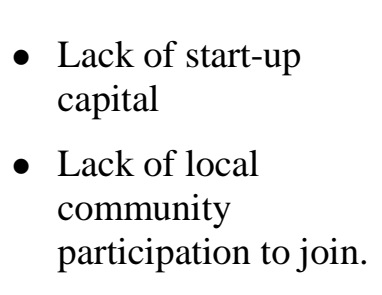 & $\begin{array}{l}\text { - Craft products have a } \\
\text { vast product market. } \\
\text { - There are local } \\
\text { government policies } \\
\text { that promote handicraft } \\
\text { products. }\end{array}$ & $\begin{array}{l}\text { The entry of new } \\
\text { competitors in the } \\
\text { craft industry } \\
\text { - Weak supply of raw } \\
\text { materials }\end{array}$ \\
\hline
\end{tabular}




\begin{tabular}{|c|c|c|c|}
\hline $\begin{array}{l}\text { S - Strength } \\
\text { (Strength) }\end{array}$ & $\begin{array}{l}\text { W - Weakness } \\
\text { (Weakness) }\end{array}$ & $\begin{array}{c}\text { O - Opportunities } \\
\text { (Opportunities) }\end{array}$ & T- Threats (Threats) \\
\hline $\begin{array}{l}\text { - Creativity in } \\
\text { developing } \\
\text { motives } \\
\text { - Availability of } \\
\text { community } \\
\text { craftsmen groups } \\
\text { - Local } \\
\text { government } \\
\text { support } \\
\text { - Traditional raw } \\
\text { materials } \\
\text { - Having Human } \\
\text { Resources (HR) } \\
\text { - The production } \\
\text { process is } \\
\text { conducted } \\
\text { traditionally. } \\
\text { - The price level is } \\
\text { varied } \\
\text { - Has a variety of } \\
\text { creative products } \\
\text { - Availability of } \\
\text { creative } \\
\text { community } \\
\text { groups } \\
\text { - The number of } \\
\text { competitors is } \\
\text { small because } \\
\text { communities } \\
\text { have different } \\
\text { skills. }\end{array}$ & $\begin{array}{l}\text { - Lack of awareness of } \\
\text { the local community } \\
\text { to try to be creative } \\
\text { - Product packaging is } \\
\text { still simple. } \\
\text { - The availability of } \\
\text { personnel is still } \\
\text { lacking. } \\
\text { - Limited production } \\
\text { - The production } \\
\text { process, which is still } \\
\text { traditional, takes a } \\
\text { longer time. } \\
\text { - The material } \\
\text { resources used are } \\
\text { quite expensive. } \\
\text { - The purchasing } \\
\text { power of innovative } \\
\text { products is still } \\
\text { lacking. } \\
\text { - Prices are difficult to } \\
\text { compete with. } \\
\text { - The place of } \\
\text { production is } \\
\text { connected to a house } \\
\text { to live in so that it } \\
\text { becomes less flexible. } \\
\text { No handicraft product } \\
\text { center can } \\
\text { accommodate the } \\
\text { production result. }\end{array}$ & $\begin{array}{l}\text { - Government support } \\
\text { with coaching and } \\
\text { training } \\
\text { - Homemade handicraft } \\
\text { products have begun to } \\
\text { be popular overseas. } \\
\text { - The use of promotional } \\
\text { media electronically is } \\
\text { increasingly advanced. } \\
\text { - Exhibitions that are } \\
\text { often held by the } \\
\text { government } \\
\text { - Exhibition sponsorship } \\
\text { from local government }\end{array}$ & $\begin{array}{l}\text { - The existence of } \\
\text { substitutes (more } \\
\text { varied substitute } \\
\text { products) } \\
\text { - The increasing } \\
\text { number of Chinese } \\
\text { products at lower } \\
\text { prices } \\
\text { - Threats from } \\
\text { decorative items } \\
\text { from outside } \\
\text { - The price of the raw } \\
\text { material keeps } \\
\text { increasing. } \\
\text { - It is difficult to find } \\
\text { the next generation } \\
\text { of artisans. Most of } \\
\text { them are elderly. }\end{array}$ \\
\hline
\end{tabular}

Source: compiled by the author from the survey results

Implementation and Evaluation of Strategy Models

Through the assessment of strengths, weaknesses, opportunities, and threats, after knowing the position of the craft industry at this time, then the SME strategy factors were developed using the SWOT matrix (Table 3). 
Table 3. Development of Competitive Craft Creative Industry Strategies

\begin{tabular}{|c|c|c|}
\hline $\begin{array}{c}\text { Internal } \\
\text { Factors }\end{array}$ & $\begin{array}{l}\text { Strengths (S) } \\
\text { 1. Tang-Sel has a large number of } \\
\text { handicraft groups } \\
\text { 2. Have a creative product community } \\
\text { relationship } \\
\text { 3. The craftsmen's innovation is } \\
\text { relatively high } \\
\text { 4. Collaborating with the government } \\
\text { 5. The skills of the craftsmen are quite } \\
\text { varied } \\
\text { 6. Products have good quality }\end{array}$ & $\begin{array}{l}\text { Weakness (W) } \\
\text { 1. Limited information on bank } \\
\text { credit facilities } \\
\text { 2. Management does not arrange } \\
\text { neatly } \\
\text { 3. Human Resources have difficulty } \\
\text { in the search for personnel in } \\
\text { addition to production } \\
\text { 4. Still limited markets and } \\
\text { marketing } \\
\text { 5. A production that is still on a } \\
\text { home industrial scale is limited to } \\
\text { orders } \\
\text { 6. Production continuity is not } \\
\text { maximal } \\
\text { 7. The existence of homemade is } \\
\text { still not widespread }\end{array}$ \\
\hline $\begin{array}{l}\text { Opportunity (O) } \\
\text { 1. Establish marketing cooperation } \\
\text { (pricing) between artisans and } \\
\text { groups } \\
\text { 2. Foreign market demand } \\
\text { 3. There are local government } \\
\text { facilities: work-training center, } \\
\text { exhibition sponsorship, training, } \\
\text { and coaching. } \\
\text { 4. There is an extensive corporate } \\
\text { CSR } \\
\text { 5. The attractiveness of handicraft } \\
\text { products in foreign markets }\end{array}$ & $\begin{array}{l}\text { S-O } \\
\text { 1. Empowering a group of craftsmen } \\
\text { optimally } \\
\text { 2. Improve coaching patterns } \\
\text { to artisans associated with } \\
\text { exhibition sponsor, showroom home } \\
\text { creative, IT applications } \\
\text { 3. Bring the craftsmen closer to } \\
\text { CSR program } \\
\text { 4. Using modern technology to } \\
\text { increase production } \\
\text { 5. Maintaining product quality } \\
\text { 6. Increasing guidance in product } \\
\text { design and packaging }\end{array}$ & $\begin{array}{l}\text { W-O } \\
\text { 1. Get closer to } \\
\text { banking and programs } \\
\text { local government assistance } \\
\text { for the strengthening of business } \\
\text { capital } \\
\text { 2. Improve skills \& training } \\
\text { for the workforce } \\
\text { 3. Developing promotional } \\
\text { programs both offline and online }\end{array}$ \\
\hline $\begin{array}{l}\text { Threat (T) } \\
\text { 1. Overseas competitors imitate } \\
\text { products at low prices } \\
\text { 2. Domestic competitors } \\
\text { 3. Increasingly higher rental } \\
\text { contracts for business premises } \\
\text { 4. There is an ASEAN free trade } \\
\text { agreement } \\
\text { 5. The availability of ready-to-use } \\
\text { technology }\end{array}$ & $\begin{array}{l}\text { S-T } \\
\text { 1. Develop cooperation with } \\
\text { Tang-Sel local government in the } \\
\text { policy of Creative house } \\
\text { 2. Protect creativity } \\
\text { product } \\
\text { 3. Provide information on quality } \\
\text { standards for craft products }\end{array}$ & $\begin{array}{l}\text { W-T } \\
\text { 1. Improve infrastructure } \\
\text { area } \\
\text { 2. Develop policies for procurement } \\
\text { /soft loan machines } \\
\text { 3. Increase capital with } \\
\text { making a loan to the government } \\
\text { through BUMN }\end{array}$ \\
\hline
\end{tabular}

Source: compiled by the author from table 2

\section{DISCUSSION}

The descriptive analysis of SMEs used as the research sample has been analyzed as many as 20 SMEs for various craft products, giving an overview of the descriptions of business owners, businesses, and other locations. The craftsmen are quite far apart, not grouping in one place. The craft center has not yet been formed, but the craftsmen camp has joined the Tangsel handicraft community group. It makes it easier to communicate information, such as information about the exhibition, other events either organized by local government and private parties. In developing and maintaining the craftsman business, it cannot separate from the competitive advantage strategy carried out by SMEs. 
The SWOT analysis result illustrates that SMEs must carry out the strategies, which the implementation of this strategy would carry out in community service activities. Fifteen strategies need to be carried out by the SMEs to increase their competitive advantage. Ginting (2017) reveals that financial and capital factors, human resources, copyright, and marketing are obstacles to developing the creative economy in West Java. This problem seems to be one reason for the cause of the optimal development of the creative industry sector in Indonesia, making it difficult to outperform competitors. To keep the SMEs in the South Tangerang area still exist and developing, the SMEs community group needs to carry out a strategy that can surpass competitors.

\section{CONCLUSION}

Through the development of strategies that need to be carried out by SMEs, there are 15 strategies, which are: S- O strategy: Empowering groups of craftsmen optimally, improving the pattern of guidance for artisans related to exhibition sponsorship, creative house showrooms, IT applicationsbringing artisans closer to the CSR program-using modern technology to increase production. Maintain product quality. The improvement of coaching in terms of design and product packaging. W-O Strategy: Closer to banking and local government assistance programs to strengthen business capital. Improve skills \& training for workers. It is developing promotional programs, both online and online. S-T Strategy: Developing cooperation with the South Tangerang Regional Government in the Creative House policy. To protect the product of creativity, someone must provide information about the quality standards of handicraft products. W-T Strategy: Improve regional infrastructure. Develop policies for machine procurement / soft loans. Increase capital by making loans to the government through BUMN.

\section{ACKNOWLEDGMENT}

The creative industry supports the implementation of this research in South Tangerang. For that, we thank you very much.

We also thank the dean of the LPPM Tarumanagara University for supporting this research.

\section{REFERENCES}

Brad, S. \& Brad, E. (2015). Enhancing SWOT analysis with TRIZ-based tools to integrate systematic innovation in early task design. Procedia Engineering, 131, 616-625.

Cojanu, V. \& Bilbor, M. R. (2007). The Swot Technique In Action: Strategic Analysis of Development in Romania. Review Of Management and Economical Engineering, 6 (5), 162167.

Florida, R. (2013, March 21). Did I Abandon My Creative Class Theory? Not So Fast, Joel Kotkin. Daily Beast. Retrieved August 25, 2020, from https://www.thedailybeast.com/did-i-abandonmy-creative-class-theory-not-so-fast-joel-kotkin.

Husein, U. (2000). Marketing Research and Consumer Assessment. Jakarta: PT Gramedia.

Jurnarsih, E (2005). Learning Experience In Creativity: A Reflective Essay. Assignment Paper. Australia: The Australian National University.

Kew, J. \& Stredwick, J. (2010). Human Resource Management In A Business Context. London: Cipd. Larassaty, A. L. (2016). Contribution of Human Resources in the Creative Industry Sector to Improve Tourism Performance (Case Study at the Culture and Tourism Office of Pasuruan Regency). Proceedings of the National Seminar on Economics and Business, 95-113.

Pahl, N. \& Richter, A. (2009). Swot Analysis-Idea, Methodology and a Practical Approach. Norderstedt: Grin Verlag. 
Sarbah, A.I. \& Otu-Nyarko, D. (2014). An Overview Of The Design School Of Strategic Management (Strategy Formulation As A Process Of Conception). Open Journal Of Business And Management, 2, 231-249.

UK DCMS Task Force (1998). Indonesian Creative Economy Development Plan, part 1 about the introduction and direction of the development of Indonesia's creative economy 2025. London.

Zimmerer, T. W., Scarborough, N. M. \& Wilson, D. (2008). Essentials of Entrepreneurship and Small Business Management, 5th Edition. New Jersey: Pearson Education Inc,

\section{Legal requirements}

The author Rodhiah guarantees that the manuscript will not be published anywhere else and in any language without the consent of the copyright holder, also the rights of third parties will not be infringed, and the publisher will not be held legally liable if there is a compensation claim.

The statements and opinions expressed in this chapter are those of the author and not the editor. There is no responsibility for accepting the accuracy of the information contained in published papers. The editor will not be responsible or liable for damage or injury to people or property arising from using any materials, methods, instructions, or ideas contained in the paper.

Authors who want to insert an image or text published elsewhere must obtain permission from the copyright holder and include evidence that such permission has been granted when handed their papers. All material received in the absence of such evidence will be deemed to be from the author. Authors are encouraged to transfer the article's copyright to the publisher when they have received the journal article by using the Guarantee Agreement and Author's Copyright Determination. 